\title{
Fruit Characteristics of 'York' Apples during Development and after Storage
}

\author{
Morris Ingle and Mervyn C. D'Souza ${ }^{1}$ \\ Division of Plant and Soil Sciences, West Virginia University, Morgantown, \\ WV 26506-6108

\section{E.C. Townsend} \\ Department of Statistics, West Virginia University, Morgantown, WV26506-6108
}

Additional index words. Malus $\times$ domestica, refrigerated-air storage, controlled-atmosphere storage, firmness, soluble solids, starch, ethylene, malic acid, superficial scald, decay

\begin{abstract}
Firmness, soluble solids concentration (SSC), starch index (SI), internal ethylene concentration (IE), and titratable acid concentration (TA) of 'York Imperial' apple (Malus $\times$ domestica Borkh.) fruit changed linearly with harvest date between 152 and 173 days after full bloom (DAFB). Firmness was positively correlated with TA, SSC was correlated with SI, and SI was negatively correlated with TA. After 150 days of refrigerated-air (RA) storage, there was no relationship between DAFB at harvest and firmness or superficial scald, but the malic acid concentration declined linearly and storage decay increased linearly with DAFB. Firmness had declined to a plateau and was not correlated with any variable at harvest. Malic acid concentration after CA storage was correlated with DAFB, firmness, SSC, and SI; scald was correlated with firmness and SI; and decay was correlated with DAFB, firmness, SSC, and SI. During 150 days of controlledatmosphere (CA) storage $\left(2.5 \% \mathrm{O}_{2}, 1.0 \% \mathrm{CO}_{2}\right)$, firmness and $\mathrm{TA}$ decreased as a linear function of DAFB. Percentage of fruit with scald and scald rating changed quadratically with DAFB, and decay increased linearly with DAFB. After 150 days of CA, firmness was correlated with DAFB, SI, and IE at harvest; TA was correlated with DAFB, firmness, SSC, TA, and SI; scald was correlated with firmness and SI; and decay was correlated with DAFB, SSC, and scald index at harvest. During 250 days of CA storage, firmness, TA, scald, and decay changed linearly with DAFB in only 1 or 2 years out of 3 . Formulas were created to predict firmness after CA within 10 to $12 \mathrm{~N}(2.0-2.5 \mathrm{lb}-\mathrm{f})$ and $\mathrm{TA}$ to within $25 \%$.
\end{abstract}

Very little has been published about the maturation and storage of 'York' (='York Imperial') apples, perhaps because 'York' is a cultivar of local importance. Although 'York' comprises only $3 \%$ of the national apple crop, it makes up $46 \%$ of the total crop in the midAtlantic states of Delaware, Maryland, Pennsylvania, Virginia, and West Virginia(Terpstra, 1991). Another reason for the lack of published information may be that a large fraction of the crop is processed directly after harvest, with little or no storage. Recently, however, some processors have been storing fruit to extend plant utilization (R. Bentley, Knouse Foods, personal communication).

Magness et al. (1926) reported that 'York', 'Winesap', 'Yellow Newtown', and 'Arkansas Black' fruit were firmer than those of 'Stayman' ('Stayman Winesap') or 'Rome Beauty' at harvest and that they all softened at about the same rate in $0{ }^{\circ} \mathrm{C}$ refrigerated-air (RA) storage. As a result, 'York' fruit reached about the same firmness as 'Stayman' and

Received for publication 23 July 1998. Accepted for publication 10 Dec. 1998. Approved for publication by the Director of West Virginia Univ. Agriculture and Forestry Experiment Station as Scientific Article No. 2466. The cost of publishing this paper was defrayed in part by the payment of page charges. Under postal regulations, this paper therefore must be hereby marked advertisement solely to indicate this fact.

${ }^{1}$ Current address: Knouse Foods Corp., Inc., Biglerville, PA 19307.
'Rome' after 1 month of additional storage. During $0{ }^{\circ} \mathrm{C}$ storage, soluble solids increased from $10 \%$ to $12 \%$ or $14 \%$, while titratable acidity (malic acid) decreased by one-third. Magness believed that the storage life of 'York' fruit was determined primarily by the development of superficial scald. If harvest were delayed until the danger of scald was past, preharvest drop could become a hazard. Haller and Smith (1950) concluded that if 'York' fruit were harvested 160 days after full bloom (DAFB), eating quality would be satisfactory until March and scald would be absent or slight and tolerable. Internal ethylene concentration and ethylene evolution rates have been suggested as guides for harvesting some apple cultivars (Dilley, 1981; Smith, et al., 1969) but these methods have not been used for 'York'.

This report describes changes in firmness, titratable acid concentration (TA), soluble solids concentration (SSC), starch index (SI), and internal ethylene concentration (IE) of 'York' fruit from 150 to $170 \mathrm{DAFB}$, and the relationship of these characteristics to firmness and disorders after RA and controlled-atmosphere (CA) storage. The overall objective was to determine if condition after storage can be predicted from some or all of the aforementioned fruit characteristics at harvest.

\section{Materials and Methods}

In Aug. 1987, five replicate trees were chosen in five commercial orchards in Berke- ley County, W.Va. The two blocks in the northern end of the county were $2 \mathrm{~km}$ apart and were separated from the three blocks in the southern part of the county by $20 \mathrm{~km}$; the latter three blocks were within $3 \mathrm{~km}$ of one another. The trees were chosen based on similar size and fruit load. All trees were 25 to 30 years old and on seedling rootstocks. In 1988 and 1990, some of the original trees did not appear to have sufficient fruit and a nearby, similar tree was substituted. There was no experiment in 1989 because spring frost resulted in nearly complete crop loss. In 1988, one site was unavailable because of frost.

On each picking date, $\approx 100$ fruit were collected from all parts around the bottom 1.5 $\mathrm{m}$ of the tree. At the laboratory, 10 fruit were drawn randomly from each replicate. Within 6 $\mathrm{h}$ of picking, IE was determined in a 1-mL gas sample withdrawn through an 18-gauge needle inserted into the core through the calyx end. In 1987 and 1988, individual fruits were sampled. In 1990, gas samples from the 10 fruit in each replicate were combined in one $10-\mathrm{mL}$ syringe before analysis. Ethylene concentration was measured with a Varian 3700 gas chromatograph fitted with an alumina column and flame-ionization detector. After the ethylene measurements had been made, firmness was measured on opposite, pared sides of the fruit with an Effegi penetrometer (11-mm tip). Soluble solids concentration in juice expressed from the outer flesh of each fruit was estimated with a calibrated hand-held refractometer (Atago N-1; McCormick Supply, Wenatchee, Wash.). Relative starch content or SI was determined, according to the Ontario SI scale (Priest and Lougheed, 1981), on fruits cut in half transversely. The halves of the apples not stained for starch were combined and frozen immediately. After some months they were thawed and juiced (Acme Juicerator; Acme Juice Co., Le Moyne, Pa.), and duplicate 10$\mathrm{mL}$ aliquots were titrated to $\mathrm{pH} 8.2$ and the malic acid concentration calculated.

Thirty-six to $48 \mathrm{~h}$ after harvest, the fruit were placed in a $0{ }^{\circ} \mathrm{C}$ storage room. About 15 $\mathrm{h}$ later, two 30-fruit samples were placed in plastic bags. One sample from each replicate was placed in a $210-\mathrm{L}$ plastic barrel. When filled, the barrel lid was sealed with petroleum jelly and a locking ring. Flow of oxygen and nitrogen gases were adjusted using rotameters and mixed to produce $2.5 \% \mathrm{O}_{2}$ in $\mathrm{N}_{2}$. This mixture was metered continuously to the barrels, using glass capillaries mounted on flow boards at the rate of $35 \mathrm{~L} \cdot \mathrm{h}^{-1}$. In 1990, the barrels were flushed with the low $\mathrm{O}_{2}$ product of a membrane gas separator as required to maintain $2.5 \% \mathrm{O}_{2}$. Carbon dioxide was maintained at $<1 \%$ by the inclusion of hydrated lime $\left(0.5 \mathrm{~kg}\right.$ per $20 \mathrm{~kg}$ fruit). The $\mathrm{O}_{2}$ level declined to $<3 \% \mathrm{O}_{2}$ within $12 \mathrm{~h}$ of closing the barrels. The other sample from each replicate was stored in open boxes in the same storage room. Fruits were stored in air for $150 \mathrm{~d}$, and in CA for 150 or $250 \mathrm{~d}$. A portion of the fruit stored for $150 \mathrm{~d}$ in CA was held for 14 or $28 \mathrm{~d}$ in RA.

After storage plus $7 \mathrm{~d}$ at $20^{\circ} \mathrm{C}$, firmness was measured with the same penetrometer 
used at harvest. Superficial storage scald was rated as none, light $(<10 \%$ of fruit surface affected), or unmarketable (>10\% affected).

Daily minimum and maximum temperatures and precipitation were measured at the Experiment Farm, Kearneysville, W.Va., 11 to $13 \mathrm{~km}$ from the collection sites. Monthly accumulated heat units (base $10{ }^{\circ} \mathrm{C}$ ) were then calculated.

Differences between sites and harvest dates were compared by orthogonal contrasts and Duncan's New Multiple Range Test, using two software packages (SAS, SAS Institute Inc., Cary, NC; MSTATC, MSTAT, Michigan State Univ., East Lansing).

\section{Results}

Temperature and precipitation. The mean temperature was highest in the 1987 growing season, although the differences between years were not large. Accumulated heat units in 1990 were $84 \%$ of those in 1987 and were similar to those in 1988. The highest total rainfall was in 1988. About twice as much rain fell in Sept. 1987, essentially the last month of fruit development, as in the other 2 years. Full bloom dates were within an 8-d interval across years.

Differences between sites were nonsignificant; therefore, the data for the four or five sites were combined and used for correlation and regression analyses.

Effect of time of harvest. When the data for the 3 years were combined, all five of the fruit characteristics measured were found to have changed linearly between 150 and 170 DAFB (Table 1). After combining data for all four harvests, the mean yearly firmness was nearly the same in 1987 and 1990 but 12 to $14 \mathrm{~N}$ less in 1988 (Table 1). SSC was nearly the same in all 3 years (Table 1). Starch index changed very slowly and never reached the mature level as defined for other cultivars (Priest and Lougheed, 1981). Internal ethylene concentration generally remained below $1 \mu \mathrm{L} \cdot \mathrm{L}^{-1}$; indeed, most of the individual readings were $\approx 0.1 \mu \mathrm{L} \cdot \mathrm{L}^{-1}$. The higher means resulted from exceptional fruits with high concentrations (data not shown). Malic acid concentration decreased with time, but this decline tended to be small and erratic. Malic acid concentration was essentially the same in 1987 and 1990 and $\approx 10 \%$ lower in 1988 (Table 1).

All of the fruit characteristics were correlated $(P \leq 0.05)$ with DAFB but $r^{2}$ values varied widely (data not shown). Firmness was correlated with TA. Soluble solids concentrations were correlated with SI. Starch index was correlated with TA in some years, but not others (Table 2). Internal ethylene concentration was correlated only with SSC.

Air storage. During storage at $0{ }^{\circ} \mathrm{C}$ in air for $150 \mathrm{~d}$, firmness declined by $23 \%$ to $36 \%$. There was no effect of time of harvest on firmness after storage (Table 2). In 1988 and 1990, firmness of fruit from all harvest times had declined to a similar level; in 1987, there were greater differences between harvest times but no trend was evident. The rate of softening of 'York' in RA storage was estimated to be

Table 1. Effect of days after full bloom (DAFB) $(1987,1988,1990$ combined) and year on firmness, soluble solids, starch index, malic acid, concentration, and internal ethylene concentration of 'York' apples at harvest.

\begin{tabular}{|c|c|c|c|c|c|}
\hline Factor & $\begin{array}{c}\text { Firmness } \\
(\mathrm{N})\end{array}$ & $\begin{array}{c}\text { Soluble solids } \\
(\%)\end{array}$ & $\begin{array}{l}\text { Starch } \\
\text { index }\end{array}$ & $\begin{array}{c}\text { Malic acid } \\
\left(\mathrm{g} \cdot \mathrm{L}^{-1}\right)\end{array}$ & $\begin{array}{c}\text { Internal } \mathrm{C}_{2} \mathrm{H}_{4} \\
\left(\mu \mathrm{L} \cdot \mathrm{L}^{-1}\right) \\
\end{array}$ \\
\hline \multicolumn{6}{|l|}{ DAFB } \\
\hline $150^{2}$ & $85.0 \mathrm{a}^{\mathrm{z}}$ & $11.3 \mathrm{c}$ & $1.1 \mathrm{~b}$ & $7.87 \mathrm{a}$ & $0.11 \mathrm{~b}$ \\
\hline 157 & $81.1 \mathrm{ab}$ & $11.6 \mathrm{c}$ & $1.3 \mathrm{~b}$ & $7.99 \mathrm{a}$ & $0.08 \mathrm{~b}$ \\
\hline 164 & $80.8 \mathrm{ab}$ & $12.3 \mathrm{~b}$ & $1.6 \mathrm{ab}$ & $7.17 \mathrm{ab}$ & $0.92 \mathrm{a}$ \\
\hline 171 & $74.7 \mathrm{~b}$ & $12.8 \mathrm{a}$ & $2.2 \mathrm{a}$ & $6.86 \mathrm{a}$ & $0.51 \mathrm{a}$ \\
\hline Significance & $\mathrm{L}^{\mathrm{y}}$ & $\mathrm{L}$ & $\mathrm{L}$ & $\mathrm{L}$ & $\mathrm{L}$ \\
\hline \multicolumn{6}{|l|}{ Year } \\
\hline 1987 & $83.0 \mathrm{a}$ & 11.9 & 1.92 & $7.56 \mathrm{a}$ & 0.32 \\
\hline 1988 & $70.6 \mathrm{~b}$ & 11.9 & 1.29 & $7.00 \mathrm{~b}$ & 1.00 \\
\hline 1990 & $85.9 \mathrm{a}$ & 12.1 & 1.36 & $7.79 \mathrm{a}$ & 0.96 \\
\hline
\end{tabular}

${ }^{2}$ Mean separation within factors and columns by Duncan's new multiple range test, $P \leq 0.05$.

${ }^{\mathrm{y}} \mathrm{L}=$ linear, $P \leq 0.01$.

Table 2. Main effects of days after full bloom (DAFB) on firmness, titratable acid concentration (TA), scald, and decay of 'York' apple after regular (RA) or controlled-atmosphere (CA) storage.

\begin{tabular}{|c|c|c|c|c|}
\hline DAFB & $\begin{array}{c}\text { Firmness } \\
(\mathrm{N})\end{array}$ & $\begin{array}{c}\mathrm{TA} \\
\left(\mathrm{mg} \cdot \mathrm{L}^{-1}\right)\end{array}$ & $\begin{array}{c}\text { Scald } \\
\text { (\% unmarketable) } \\
\end{array}$ & $\begin{array}{c}\text { Decay } \\
(\%)\end{array}$ \\
\hline \multicolumn{5}{|c|}{$150 \mathrm{~d}$ RA plus $7 \mathrm{~d}$ at $20^{\circ} \mathrm{C}$} \\
\hline 150 & 55 & 4930 & 36.4 & 10.3 \\
\hline 157 & 52 & 4230 & 49.3 & 14.7 \\
\hline 164 & 54 & 4180 & 39.0 & 29.1 \\
\hline 171 & 54 & 3910 & 39.9 & 36.8 \\
\hline Significance & NS & $\mathrm{L}$ & NS & $\mathrm{L}$ \\
\hline \multicolumn{5}{|c|}{150 d CA plus 7 d at $20^{\circ} \mathrm{C}$} \\
\hline 150 & 67 & 4640 & 32 & 1.5 \\
\hline 157 & 66 & 4330 & 41 & 0.6 \\
\hline 164 & 66 & 4150 & 55 & 2.3 \\
\hline 171 & 57 & 4130 & 32 & 22.2 \\
\hline Significance & NS & NS & NS & $\mathrm{L}$ \\
\hline \multicolumn{5}{|c|}{$150 \mathrm{~d}$ CA plus $14 \mathrm{~d}$ RA plus $7 \mathrm{~d}$ at $20^{\circ} \mathrm{C}$} \\
\hline 150 & 68 & 4790 & 56 & \\
\hline 157 & 66 & 4190 & 47 & \\
\hline 164 & 68 & 4090 & 64 & \\
\hline 171 & 58 & 3740 & 51 & \\
\hline Significance & Q & $\mathrm{L}$ & $\mathrm{L}$ & \\
\hline \multicolumn{5}{|c|}{$150 \mathrm{~d}$ CA plus $28 \mathrm{~d}$ RA plus $7 \mathrm{~d}$ at $20^{\circ} \mathrm{C}$} \\
\hline 150 & 67 & 4020 & 52 & 2 \\
\hline 157 & 63 & 4240 & 47 & 7 \\
\hline 164 & 61 & 3840 & 55 & 6 \\
\hline 171 & 51 & 3730 & 32 & 25 \\
\hline Significance & $\mathrm{L}$ & NS & NS & $\mathrm{L}$ \\
\hline \multicolumn{5}{|c|}{$250 \mathrm{~d}$ CA plus 7 d at $20^{\circ} \mathrm{C}$} \\
\hline 150 & 68 & 4870 & 62 & 15 \\
\hline 157 & 70 & 4710 & 53 & 13 \\
\hline 164 & 69 & 4400 & 61 & 22 \\
\hline 171 & 60 & 3500 & 7 & 43 \\
\hline Significance & $\mathrm{L}$ & $\mathrm{L}$ & NS & $\mathrm{L}$ \\
\hline
\end{tabular}

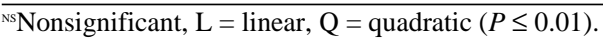

0.1 to $0.25 \mathrm{~N} \cdot \mathrm{d}^{-1}$. Malic acid concentrations declined linearly with DAFB in all 3 years. Superficial scald increased linearly with DAFB in 1988 but decreased linearly in 1990. There was much less scald in 1987 and the severity bore no relation to harvest time. The percentage of decayed fruits increased as maturity advanced, but the relationship was most evident in 1988 (Table 2). There were no significant correlations between characteristics at harvest and after $150 \mathrm{dRA}$, except for SSC and TA after storage $(r=-0.29, P \leq 0.05)$.

Controlled-atmosphere storage. After 150 d of CA storage, fruits from the 1987 and 1990 crops had lost $20 \%$ to $30 \%$ of their initial firmness (Table 1), but those from the 1988 crop, which were less firm at harvest, lost almost none. Firmness loss during CA was a linear function of DAFB; percent loss did not change with DAFB. The rate of loss was 0.04 to $0.15 \mathrm{~N} \cdot \mathrm{d}^{-1}$. Malic acid concentration also decreased linearly with DAFB, and the $40 \%$ to $50 \%$ decline was very similar to the loss in RA (Table 1). In 1987 and 1990 scald during CA was as great or greater than that in RA storage; in 1988 there was more scald after RA storage. One notable effect of CA was the suppression of decay.

There were a number of significant correlations between fruit characteristics at harvest and after CA (Table 3). Starch index was associated with firmness, TA, and decay after storage, but not with scald (Table 3); DAFB and IE also influenced firmness after storage. 
Malic acid concentration after CA was correlated with DAFB, and with TA, firmness, and SSC at harvest (Table 3). After transfer from CA to RA, the rates of decline in firmness and TA became similar to the rates in continuous RA (data not shown), scald increased by $10 \%$ to $15 \%$, and decay became excessive only for the last harvest date.

When held in CA for $\approx 250 \mathrm{~d}$, the rate of softening for the last $100 \mathrm{~d}$ was $<0.038 \mathrm{~N} \cdot \mathrm{d}^{-1}$ (Table 2). Firmness still declined linearly with DAFB. About $10 \%$ more of the malic acid disappeared between 150 and $250 \mathrm{~d}$ of storage. During this period, scald increased $58 \%$ to $81 \%$ in the 1988 crop and $21 \%$ to $61 \%$ in the 1990 crop; scald was fairly high after $150 \mathrm{dCA}$ in the latter. Decay increased with DAFB. Correlations between fruit characteristics at harvest and after $250 \mathrm{~d}$ were much the same as after $150 \mathrm{~d}$ CA storage.

Using the best correlations in Table 3, prediction equations for firmness were calculated (Table 4). Equation 4 had the highest $R^{2}$ after $150 \mathrm{~d}$ and Equation 7 after $250 \mathrm{~d}$ CA storage. Both use DAFB, SI, and SSC at harvest. Observed firmness agreed well with predicted firmness calculated from the same data set from which the formulas were derived (Table 5). The ratio of observed/predicted firmness ranged from 0.95 to 1.05 .

\section{Discussion}

Firmness loss on the tree between 150 and 170 DAFB ranged from 4.4 N in 1990 to 14.5 $\mathrm{N}$ in 1987. The high softening rate in 1987 may be attributable to the highest seasonal temperature of the 3 years (data not shown). The first 2 weeks of Oct. 1987 were colder than the comparable periods in 1988 or 1990 . By comparison, over a 3-week period in 1983 and 1994, five 'Delicious' strains softened 4 to 13 N (Ingle and D'Souza, 1989). There was no apparent relationship between firmness and rainfall over any period. Sept. 1987 had more than twice as much rainfall as Sept. 1988 or 1990 , but fruit in 1990 was only $4 \mathrm{~N}$ less firm than in 1987. Total rainfall was greatest in 1988 , but fruit were the least firm of the 3 years. There was essentially no difference in SSC between the 3 years and changes in SSC on the trees were similar. Some strains of 'Delicious' have higher total soluble solids than does 'York', but overall the differences were not striking (Ingle and D'Souza, 1989). The starch index remained low over the $21 \mathrm{~d}$ between the first and last fruit collections, and changed much less than was observed in 'Delicious' (Ingle and D'Souza, 1989). The 'mature' level starch index of 4-5 as defined by Blanpied and Silsby (1993) or Priest and Lougheed (1981) was never reached, even though fruit drop had become severe.

Dilley (1981) suggested that $1 \mu \mathrm{L} \cdot \mathrm{L}^{-1}$ IE indicates that the climacteric is in progress and autocatalytic production has commenced, and that storage potential will be limited. While average ethylene concentrations were always $<1 \mu \mathrm{L} \cdot \mathrm{L}^{-1}$, values were higher in some fruit. In $1987,2 \%$ of the fruit at two sites had levels $>1 \mu \mathrm{L} \cdot \mathrm{L}^{-1}$ at the first harvest. By the third

Table 3. Correlation $(r)$ matrix between 'York' apple fruit characteristics at harvest and after $150 \mathrm{~d}$ controlled atmosphere plus $7 \mathrm{~d}$ at $20^{\circ} \mathrm{C}$. Data for $1987,1988,1990$ combined.

\begin{tabular}{lcccc}
\hline \hline \multirow{2}{*}{$\begin{array}{l}\text { Characteristic } \\
\text { at harvest }\end{array}$} & $\begin{array}{c}\text { Characteristic after storage } \\
\text { Firmness } \\
\text { DAFB }\end{array}$ & $\begin{array}{c}\mathrm{TA}^{\mathrm{z}} \\
\left(\mathrm{mg} \cdot \mathrm{L}^{-1}\right)\end{array}$ & $\begin{array}{c}\text { Scald } \\
(\% \text { unmarketable })\end{array}$ & $\begin{array}{c}\text { Decay } \\
(\%)\end{array}$ \\
\hline Firmness & $-0.35^{*}$ & $-0.56^{*}$ & 0.06 & $0.43^{*}$ \\
SSC & -0.18 & $0.42^{*}$ & $0.50^{*}$ & -0.16 \\
SI & -0.22 & $0.33^{*}$ & 0.06 & $0.39^{*}$ \\
IE & $-0.50^{*}$ & $-0.54^{*}$ & 0.12 & $0.83^{*}$ \\
TA & $-0.37^{*}$ & 0.15 & 0.24 & 0.09 \\
& -0.08 & $0.51^{*}$ & 0.14 & 0.09
\end{tabular}

${ }^{\mathrm{z}} \mathrm{DAFB}=$ days after full bloom; $\mathrm{SSC}=$ soluble solids concentration; $\mathrm{SI}=$ starch index; $\mathrm{IE}=$ internal ethylene concentration; TA = titratable acid concentration.

* Significant at $P \leq 0.05$.

Table 4. Prediction equations for firmness $(\mathrm{N})$ of 'York' apples after 150 or $250 \mathrm{~d}$ of controlled-atmosphere (CA) storage plus $7 \mathrm{~d}$ at $20^{\circ} \mathrm{C}$.

\begin{tabular}{|c|c|c|c|}
\hline Variable used & Equation & $R^{2}$ & $P$ \\
\hline \multicolumn{4}{|c|}{ After $150 \mathrm{~d} C A$} \\
\hline 1. $\mathrm{DAFB}^{\mathrm{z}}$ & $\mathrm{Y}^{\mathrm{y}}=130.12-0.41 \mathrm{DAFB}$ & 0.29 & 0.0005 \\
\hline 2. SI & $\mathrm{Y}=71.60-4.39 \mathrm{SI}$ & 0.29 & 0.0005 \\
\hline 3. DAFB and SI & $\mathrm{Y}=108.32-0.25 \mathrm{DAFB}-2.65 \mathrm{SI}$ & 0.35 & 0.0006 \\
\hline 4. DAFB, SI, and SSC & $\mathrm{Y}=111.78-0.41 \mathrm{DAFB}-2.47 \mathrm{SI}+1.92 \mathrm{SSC}$ & 0.36 & 0.0006 \\
\hline \multicolumn{4}{|c|}{ After $250 \mathrm{~d} C A$} \\
\hline 5. DAFB & $\mathrm{Y}^{\mathrm{x}}=107.75-0.25 \mathrm{DAFB}$ & 0.09 & 0.10 \\
\hline 6. DAFB and SSC & $\mathrm{Y}=100.05-0.61 \mathrm{DAFB}+5.39 \mathrm{SSC}$ & 0.19 & 0.05 \\
\hline 7. DAFB, SI, and SSC & $\mathrm{Y}=88.57-0.52 \mathrm{DAFB}-3.42 \mathrm{SI}+5.48 \mathrm{SSC}$ & 0.20 & 0.10 \\
\hline
\end{tabular}

${ }^{2} \mathrm{DAFB}=$ days after full bloom; $\mathrm{SI}=$ starch index; $\mathrm{SSC}=$ soluble solids concentration.

${ }^{y}$ Firmness $(\mathrm{N})$ after $150 \mathrm{~d}$ CA.

${ }^{x}$ Firmness (N) after $250 \mathrm{~d}$ CA.

Table 5. Comparison of observed firmness vs. firmness estimated by Equations 1-7 (Table 4) and ratios between observed and estimated firmness.

\begin{tabular}{|c|c|c|c|c|c|c|c|c|c|}
\hline \multirow[b]{4}{*}{$\mathrm{DAFB}^{\mathrm{z}}$} & \multicolumn{9}{|c|}{ Treatment } \\
\hline & \multicolumn{4}{|c|}{$150 \mathrm{~d} \mathrm{CA}^{\mathrm{z}}$ plus $7 \mathrm{~d}$ at $20^{\circ} \mathrm{C}$} & & \multicolumn{4}{|c|}{$250 \mathrm{~d}$ CA plus $7 \mathrm{~d}$ at $20^{\circ} \mathrm{C}$} \\
\hline & \multirow[b]{2}{*}{ Observed } & \multicolumn{4}{|c|}{ Firmness (N) (estimated) } & \multirow[b]{2}{*}{ Observed } & \multicolumn{3}{|c|}{ Firmness $(\mathrm{N})$ estimated } \\
\hline & & Eq. 1 & Eq. 2 & Eq. 3 & Eq. 4 & & Eq. 5 & Eq. 6 & Eq. 7 \\
\hline 150 & 66.8 & 66.8 & 67.7 & 67.7 & 68.9 & 68.2 & 70.3 & 70.2 & 69.7 \\
\hline 157 & 65.9 & 65.8 & 65.4 & 65.4 & 66.3 & 69.5 & 68.5 & 67.2 & 67.2 \\
\hline 164 & 65.9 & 62.9 & 62.9 & 62.9 & 64.3 & 68.6 & 66.8 & 66.3 & 66.0 \\
\hline \multirow[t]{3}{*}{170} & 57.1 & 60.1 & 60.0 & 57.1 & 59.7 & 59.6 & 65.0 & 64.9 & 64.2 \\
\hline & & \multicolumn{8}{|c|}{ Observed/estimated ratio } \\
\hline & & Eq. 1 & Eq. 2 & Eq. 3 & Eq. 4 & & Eq. 5 & Eq. 6 & Eq. 7 \\
\hline 150 & & 0.97 & 1.02 & 0.99 & 0.97 & & 0.97 & 0.97 & 0.98 \\
\hline 157 & & 1.00 & 1.01 & 1.02 & 0.99 & & 1.02 & 1.03 & 1.04 \\
\hline 164 & & 1.05 & 1.03 & 1.05 & 1.02 & & 1.03 & 1.04 & 1.04 \\
\hline 171 & & 0.95 & 0.95 & 0.97 & 0.96 & & 0.92 & 0.92 & 0.93 \\
\hline Mean & & 0.99 & 1.00 & 1.01 & 0.99 & & 0.98 & 0.97 & 1.00 \\
\hline
\end{tabular}

${ }^{\mathrm{z}} \mathrm{CA}=$ controlled atmosphere; DAFB = days after full bloom.

harvest, as many as $25 \%$ of the fruits from one site contained an IE of $\geq 1 \mu \mathrm{L} \cdot \mathrm{L}^{-1}$. By the last harvest the average IE at that site was $1 \mu \mathrm{L} \cdot \mathrm{L}^{-1}$ with a frequency of $50 \%$. In 1988 , none of the fruit tested over the 21-d period had an IE $>1$ $\mu \mathrm{L} \cdot \mathrm{L}^{-1}$. Because combined samples were used in 1990, we cannot tell if some fruit contained $>1 \mu \mathrm{L} \cdot \mathrm{L}^{-1}$, but there cannot have been many or the average values would have been higher.

The most important 'York' fruit characteristics after storage are firmness, acidity, scald incidence, and decay. Most of these were significantly correlated with at least one characteristic at harvest. Firmness after RA storage was the quality least correlated with atharvest characteristics, including DAFB, because a common firmness plateau apparently had been reached by $150 \mathrm{~d}$; this time may be beyond the RA limit for 'York' in that scald and decay percentages were unacceptably high and usually nonsignificant with respect to DAFB.

Since firmness after 150 or 250 d CA storage was significantly correlated with DAFB, SSC, and SI, prediction equations were calculated (Table 10). These equations can be used to provide a general guide for predicting firmness of 'York' apples after CA storage. Days after full bloom, SSC, or SI never accounted for $>13 \%$ of the variation in firmness. Table 5 compares the observed firmness after 150 and $250 \mathrm{~d}$ CA storage with firmness estimated by Equations 1-4 and 5-7 in Table 4. After $150 \mathrm{~d}$ CA the observed firmness was $95 \%$ to $105 \%$ of the estimated firmness; after $250 \mathrm{~d} \mathrm{CA}$, the range was $91 \%$ to $104 \%$ of the estimate. The estimated firmness was generally less than the observed firmness. The small difference between observed and estimated values is not surprising since the latter were 
derived from the former. The equations need to be calibrated with independent harvests over several sites and times. Identification of lots that would contain excessively soft fruits, and suggesting constant monitoring and earlier removal, would be possible. Formulas 4 and 7 use DAFB, SSC, and SI, and are therefore easy to use. Recently, Evensen et al. (1993) reported that harvest firmness and SSC of 'York' fruit could be used to predict firmness if firmness is greater than a target value after several storage systems. They also found that firmness could be predicted more accurately after CA storage than after refrigerated storage, and suggested that "date of harvest" could be substituted. The relationship between IE, ethylene production, or SI and poststorage firmness was not mentioned. The most useful fruit parameter for predicting 'York' firmness was DAFB, which agrees with the findings of Haller and Smith (1950) for several apple cultivars and Ingle and D'Souza (1989) for 'Delicious'.

No attempts were made to calculate pre- dictive equations for TA, scald, or decay because there were no consistent effects of DAFB (Tables 2 and 3) and there were no fruit characteristics at harvest that accounted for a very large percentage of the variation. Essentially the same was true of decay.

Prediction equations were also calculated for TA, since it was always significantly correlated with SI (Table 1). Soluble solids concentrations were usually correlated with TA, but multiple regression did not sufficiently improve predictive precision to make this measurement worthwhile. None of the $R^{2}$ values were $>0.05$. Thus these formulas predict TA within only $25 \%$, which makes them of limited use. Correlations of scald and decay with at-harvest variables were not high enough to justify regression analysis.

\section{Literature Cited}

Blanpied, G.D. and K.J. Silsby. 1993. Predicting harvest date windows for apples. Cornell Univ. Coop. Ext. Info. Bul. 221.

Dilley, D.R. 1981. Assessing fruit maturity and ripening and techniques to delay ripening in storage. Proc. Mich. State Hort. Soc. 110:132146.

Evensen, K., P. Hammer, R. Crassweller, G. Greene, and L.L. Salada. 1993. Predicting firmness of 'York Imperial' apples. HortTechnology 3:318-322.

Haller, M.H. and E. Smith. 1950. Evaluation of indexes of maturity for apples. U.S. Dept. Agr. Tech. Bul. 1003.

Haller, M.W., J.M. Lutz, and E.D. Mallison. 1944. The relation of firmness to ripeness of eastern grown apples. U.S. Dept. Agr. Circ. 579.

Ingle, M. and M.C. D'Souza. 1989. Fruit characteristics of 'Red Delicious' apple strains during maturation and storage. J. Amer. Soc. Hort. Sci. 114:776-780

Magness, J.R., H.C. Diehl, and M.H. Haller. 1926. Picking maturity of apples in relation to storage. U.S. Dept. Agr. Bul. 1448.

Priest, K.C. and E.C. Lougheed. 1981. Evaluating apple maturity using the starch-iodine test. Ontario Ministry of Agr. and For. Agdex 211/59.

Smith, R.B., E.C. Lougheed, and E.W. Franklin. 1969. Ethylene production as an index of maturity for apples. Can. J. Plant Sci. 49:805.

Terpstra, A.E. 1991. Market doors open to U.S crops. Amer. Fruit Grower 111(9):6-7. 